\title{
Radvanický pivovar
}

\section{Brewery Radvanice}

\section{MILAN STAREC}

Dej Bůh štěstí s. r. o., Českobrodská čp. 17, 28163 Kostelec nad Černými lesy e-mail: kvetak@pivovarkostelec.cz

Starec, M.: Radvanický pivovar. Kvasny Prum. 56, 2010, č. 1, s. 24-27.

$\checkmark$ roce 1858 zbudoval v Radvanicích pivovar Josef Neumann. Roku 1871 byly vystavěny sklepy a spilky s lednicemi, následně byl pivovar rekonstruován na parní pohon. V letech 1887-1888 byla vystavěna moderní sladovna rozšířením stávajících humen a zbudováním mohutného dvojlískového hvozdu. První známý výstav z roku 1871 byl $8658 \mathrm{hl}$ a postupně narůstal k přibližně $25000 \mathrm{hl}$ na počátku 90. let 19. století. Roku 1901 byla sladovna vybavena moderními stroji na čištění ječmene a sladu. Roku 1908 koupilo pivovar vídeňské dělnické družstvo s názvem „První moravsko-slezský dělnický pivovar Skaret a spol. v Radvanicích“. Pivovar byl elektrifikován, varna modernizována. V kampani 1912/1913 bylo vystaveno 35000 hl piva. Po první světové válce, která znamenala útlum výroby a změnu vlastníka, začal pivovar prosperovat. V sezoně 1920/21 dosáhl opět výstavu 35000 hl. V letech 1925-1926 proběhla modernizace umělého chlazení, spilka byla vybavena novými káděmi, sklep novými ležáckými sudy a hliníkovými tanky. Dobře prosperující podnik byl 17. 10. 1925 přeměněn na „První moravsko-slezský pivovar a sladovna akc. spol.“. V kampani 1929/30 bylo dosaženo absolutního maxima 48000 hl vystaveného radvanického piva. Velká hospodářská krize znamenala počátek krachu pivovaru, který v roce 1937 ukončil činnost.

Starec, M.: Brewery Radvanice. Kvasny Prum. 56, 2010, č. 1, s. 24-27.

The brewery in Radvanice was established by Josef Neumann in 1858. In 1871 cellars and fermenting cellar with iceboxes were built, subsequently the brewery was reconstructed to a steam-driven facility. In 1887-1888 the malting floor was extended and a modern malthouse with a large two-floor kiln was built. The first known output in 1871 was $8658 \mathrm{hl}$ and gradually it was increased to approximately $25000 \mathrm{hl}$ at the beginning of the 1890s. In 1901 the malthouse was equipped with modern barley and malt cleaning machinery. In 1908 the brewery was bought by a Vienna workers' union named the 'First Moravian-Silesian Workers' Brewery Skaret and comp. in Radvanice“. The brewery was electrified, the brewhouse modernized. In the 1912/1913 campaign the output was $35000 \mathrm{hl}$ of beer. After the First World War, which meant a decline in production and change of the owner, the brewery's prosperous era began. In 1920/21 the output of $35000 \mathrm{hl}$ was again achieved. During 1925-1926 the system of artificial cooling was modernized, a fermenting cellar was furnished with new tubs, cellar was equipped with new storage vats and aluminum tanks. On October 171925 this well-performing plant was transformed to the First Moravian-Silesian Brewery and Malthouse, a joint stock company". During the campaign of 1929/30 Radvanice beer achieved the absolute maximal output of $48000 \mathrm{hl}$. Big economic crisis meant the beginning of the brewery's bankruptcy and closing down of the brewery in 1937.

Starec, M.: Brauerei Radvanice. Kvasny Prum. 56, 2010, Nr. 1, S. 24-27.

Im Jahre 1858 in Radvanice (heute Stadtteil der Stadt Ostrava) hat Josef Neumann eine Bierbrauerei gebaut. Im Jahre 1871 wurden Gär- und Lagerkeller und Eiskeller ausgebaut und anschließend wurde die Brauerei auf Dampfantrieb umgestellt. In den Jahren 1887 - 1888 wurde durch Verbreitung vorhandenen Tennen eine moderne Mälzerei mit der großen Zweihordendarre aufgebaut. Der erste bekannte Ausstoß vom Jahre 1871 wurde 8658 hl und stufenweise nahm zu, bis zum am Anfang des Jahres 1890 wenn es etwa 25000 hl erreichte. Im Jahre 1901 wurde die Mälzerei mit modernen Maschinen zur Gersten- und Malzreinigung ausgerüstet. Im Jahre 1908 hat eine wienerische Arbeiter-Genossenschaft die Brauerei unter Namen „První moravsko-slezský dělnický pivovar Skaret a spol. v Radvanicích" (Erste mährische und schlesische Arbeiter Brauerei Skaret und Gesellschaft in Radvanice) gekauft. Die Bierbrauerei wurde elektrifiziert und das Sudhaus renoviert. In der Saison 1912/1913 wurde 35000 hl Bieres gebraut. Nach dem ersten Weltkrieg, der der Bierbrauerei eine Dämpfung und einen Besitzwechsel verursachte, hat die Brauerei wieder prosperiert, in der Saison 1920/1921 wurde der Ausstoß wieder 35000 hl. In den Jahren 1925/1926 wurde eine Modernisierung der Maschinenkühlung durchgeführt, der Gärkeller mit neuen Gärbottichen und Lagerkeller mit neuen Lagerfässern und Alutanks ausgerüstet. Am 17.10.1925 wurde die Brauerei auf „První moravsko-slezský pivovar a sladovna akc. spol.“ (Erste mährische und schlesische Brauerei und Mälzerei, Aktien Gesellschaft) umbenannt. In der Saison 1929/1930 wurde der allerhöchste Ausstoß 48000 hl Radvanicky Bieres erreicht. Die große Wirtschaftskrise hat Anfang des Krachs der Brauerei verursacht, die im Jahre 1937 eingestellt wurde.

\section{Klíčová slova: historie, pivovar, Radvanice}

Historicky slezská část současného Statutárního města Ostrava byla před zhruba stoletím centrem spiritistického hnutí, sídlem esperantistů a abstinenčního spolku, avšak místní lihovar s chvalně známou Radvanickou hořkou a proslulý pivovar se svým vyhlášeným mokem byly bezpochyby místním abstinentům trnem v oku.

\section{PROLOG}

Obec byla osnována s největší pravděpodobností na prèlomu 13. a 14. století a písemně doložena roku 1305 v soupise desátků vratislavského biskupství. Od 15. století byly Radvanice součástí slezskoostravského panství. $V$ polovině 17 . století koupil část Radvanic Jan Skrbenský z Hřŕště a připojil je ke svému šenovskému panství. Jan Jaroslav Skrbenský z Hřišš̌ za čas díl Radvanic vsi Lipinu a Bartovice osamostatnil. Sídlem se stal zámek v sousedních Bartovicích. Dokonce v Radvanicích založil dvưr. O vaření piva však ani zmínka. Jan Max Skrbenský z Hř́ště opět Radvanice roku 1738 připojil k šenovskému panství. Při dělení majetku Skrbenských připadla radvanická část ke kunčickému panství. Druhá část Radvanic, tzv. dolní Radvanice, stále patřila k slezskoostravskému panství.

V druhé polovině 18. století Skrbenští prodali kunčickou část panství a po řadě epizodních vlastníků kunčického panství byl ve dvacátých letech 19. století díl Radvanic s Lipinou osamostatněn. Jak by se zdálo logické, že pivovar vznikne na svobodné části $\mathrm{Ra}$ dvanic, tak zde tomu tak nebylo. Přesně naopak. Malý pivovarský provoz vznikl na slezskoostravské části Radvanic, jež patřila hrabatům Wilczkům. Hrabě Franz Josef Wilczek se nevydal obvyklou cestou zásobován svého panstvíz jednoho centrálního pivovaru, konkrétně svého zámeckého pivovaru na Slezské Ostravě, ale zcela se věnoval výnosnému hornictví a ve svých poddanských vsích pronajímal právo výroby piva a prodeje alkoholických nápojů. Této činnosti se téměĭ bez výjimky věnovali židovští obchodníc a v případě Radvanic se jimi stali Josef a Karolína Neumannovi, př́slušníci jednoho z nejstarších židovských rodů ve slezské části Ostravska. Izraelité se na pravém břehu Ostravice na slezskoostravském panství usazovali již od 16. století a svou činorodou praci pomáhali vrchnosti $v$ jejich sporech se sousedním poddanským městem Moravskou Ostravou, odkud byli židé vyháněni.

\section{JOSEF NEUMANN}

Kde přesně původní pivovárek stával, se doposud neví. Měl být součástí starého zájezdního hostince u Císařské cesty (dnešní Těšínská), který dříve patřil rodině Pěčonků. 8. 10. 1813 (někdy se uvádí 1810) přešla krčma do vlastnictví vrchnosti, tedy hraběcího rodu Wilczků. Ti vzápětí hostinec pronajali včetně práva vaření piva výše uvedeným Josefu a Karolíně Neumannovým. Přesný datum ani lokalizaci neznáme. Některé zdroje uváděly číslo 27 či 28 a jiné 29. Číslování bylo bezesporu několikráte změněno a místo pù- 
vodního hostince se nepodařilo lokalizovat. Dle knihy „Radvanice a Bartovice v letopisech a obrazech 1305-2005" byl starobylý hostinec číslo 28 na místě dnešní pekárny MAYAK, ale na indikační skice stabilního katastru žádný zděný či kamenný objekt v těchto místech nestál. Jedině by to byl dřevěný hostinec. Což je samožrejmě možné. Panská krčma byla uváděna na rohu dnešní Těšínské a Lihovarské (Čapkovy) ulice. Zřejmě místo dnešního hostince U Břenků či pozdějšího lihovaru. Nepředpokládám, že by hostinec stál $\checkmark$ místech pozdějšíno pivovaru, protože to bylo relativně daleko od hlavní cesty. A tak od domněnek $\mathrm{k}$ faktům a od hostinského pivovárku $\mathrm{k}$ pivovaru.

Josef Neumann se svou chotí Karolínou 28. 6 . 1850 pronajatý hostinec s právem výroby piva odkoupili a postupně zbudovali rodinnou firmu, jež zahrnovala pivovárek, lihovar, droždárnu, octárnu, množství polí a devět dětí. Pivovar samotný s číslem 27 byl zbudován roku 1858 a nalézal se na místě, kde jeho skrovné zbytky můžeme nalézt dodnes. Před tímto rokem se o pivovaru nedá mluvit a byl to nejspíše jen kotlík a sklep jako součást zájezdního hostince. Od roku 1863 se firma jmenovala „Josef Neumann \& Co“. Pivovar byl zcela jistě na ruční pohon a nenalezli jsme žádné bližší informace o jeho provozech, sládcích či přesnější určení data založení. Víme jen, že původní otevřený nýtovaný varní kotel pocházel z železáren ve Frýdlantu nad Ostravicí. V Kneifelově topografii Slezska z roku 1804 ani ve stabilním katastru z roku 1836 pivovar zachycen nebyl. Literatura v některých prípadech uvádí datum vzniku radvanického pivovaru 1840 , ale to nepředpokládám. Zřejmě to byl jen reklamní počin s důrazem na co nejdelší tradici, která se vztahovala nejspíše k založení rodinné firmy a ne pivovaru samotnému.

\section{EMANUEL NEUMANN}

Roku 1868 po smrti Josefa Neumanna zdědil pivovar jeho prvorozený syn Emanuel. Ten se velkoryse pustil do modernizace pivovaru a hledání vhodných odbytištt. Roku 1871 vystavěl nové sklepy a spilky s lednicemi firmou J. V. Novák (předchůdce proslulé firmy Novák \& Jahn). Znamenalo to zřejmě přechod ze svrchního na spodní kvašení. V následujících letech byl pivovar rekonstruován na parní pohon. Jako první na Ostravsku vůbec! Dále byla v letech 1887-1888 (v kronice Radvanic uvedeno 1894) vystavěna na svou dobu moderní sladovna rozširrením stávajících humen a zbudováním mohutného dvojlískového hvozdu. Na plánech v pseudogotickém stylu $s$ okrasnými cimbuřími. Ve skutečnosti malinko prostší. Rekonstrukcíbyla plocha humen zvětšena o $350 \mathrm{~m}^{2}$ na celkovou plochu cca $840 \mathrm{~m}^{2}$ a nově vystavěný dvojlískový hvozd měl plochu jedné lísky $50 \mathrm{~m}^{2}$. Máčení ječmene probíhalo ve čtyřech obdélných náduvnících. Nad humny byla tři patra sladových a ječných půd. Stavitel - firma Martinka \& Co. Praha Bubny. $V$ literatuře uváděná parostrojní sladovna a pivovar je zřejmý omyl a pohon párou se týkal jen pivovaru. Dle plánů sladovny $z$ let 1887-1888 ještě nebyla sladovna mechanizována a otop hvozdu byl prímý na uhlí. Mechanizace sladovny proběhla roku 1901 a pohon byl zřejmě již elektrický. Dále bylo vystavěno v roce 1890 zcela nové sklepní hospodářství vedle sladovny směrem $\mathrm{k}$ těšínské silnici. Mezi charakteristické prvky každého pivovaru patříval vždy i pivovarský rybník či rybníky. $V$ př́ipadě Radvanic tomu bylo poněkud jinak. Mimo vlastní rybník u říčky Lučiny směrem k lipinské kolonii se ledovalo tím způsobem, že se na vhodně situovanou louku vypustila voda z ríčky a nechala zmrznout. Voda se $v$ príhodných mrazech připouštěla, aby se vytvořila co největší vrstva ledu. Poté už se postupovalo jako při klasickém ledování. Led se nepoužíval jen pro pivovar a jeho hostince. Byl ještě navíc na prodej. Původní pivovarský ledovací prostor se nacházel v místě dnešního hřiště TJ Baník.

Pivovar se nazýval „Radwanitzer Dampfbrauerei E. NEUMANN \& SOHN Radwanitz bei Mähr.-Ostrau“ (obr. 1). V roce 1889 totiž do firmy pristoupil prvorozený syn Emanuela Neumanna Arthur. Výše uvedené modernizační kroky vedly k několikanásobnému zvýšení výroby piva. První známý výstav z roku 1871 byl $8658 \mathrm{hl}$ a postupně narůstal k přibližně $25000 \mathrm{hl}$ na počátku 90 . let 19 . století. Sládci se $v$ době, kdy pivovar patřil Neumannům, střídali velmi rychle. Dalo by se s nadsázkou říci každoročně, přičemž první známý sládek byl Vilém Kolečko a nejdéle vytrvavší Hanuš Stingl (celých pět let od roku 1893 do 1898). Nebylo to náhodou povahou židovských obchodníků?

Roku 1874 zakoupil Emanuel Neumann dům na hlavním ostravském náměstí, vyvázal jej z propinace a vybudoval $v$ něm radvanickou pivnici. Koupí tohoto tzv. velkoměštanského domu si nejenom zajistil slušný odbyt svého piva, ale také se stal moravskoostravským právovárečníkem. To pro něj mělo efekt jak finanční z právovárečných podílů, tak i rozhodovací ve věcech ostravského měštanského pivovaru. V letech 1891-1893 byla budova od základů prestavěna $v$ historizujícím stylu s bohatě členěnou a barevně zdobenou fasádou. Po přestavbě to již nebyla jen radvanická pivnice, ale i hotel Gambrinus s kavárnou a společenským sálem. Centrum společenského dění v samém centru bouřlivě se rozrůstající ostravské aglomerace bylo určitě velkým odbytištěm radvanických piv a hotel hostil množství osobností. Jmenujme alespoň arcivévodu Rainera Ferdinanda Habsburského. Škoda, že se nedochovala nějaká zprávička z tisku, jak hlavě pomazané chutnalo radvanické. Stavitelem nového hotelu s pivnicí nebyl nikdo jiný než významný architekt Felix Neumann, syn Emanuela Neumanna. Tento stavební inženýr se po praxi ve vídeňských a berlínských projekčních kance- lářích věnoval architektuře na Ostravsku. Mimo již zmíněný hotel Gambrinus a přestavbu radvanického pivovaru v roce 1901 vystavěl také vilu Terezu pro pivovarského magnáta Strassmanna, Německý dům, kavárnu Union, Vítkovickou synagogu a mnohé další. A $\vee$ neposlední řadě je nutné zmínit, že $v$ místech dvorního traktu hotelu Gambrinus zasahujícího do současného Jiráskova náměstí kdysi stával prapůvodní biskupský pivovar. Tento hotel nebyl jedinou Neumannovou hostinskou aktivitou. Podnikatel si v okolí pronajímal a kupoval množství hostinců, kde prodával své výrobky. Přestavěný objekt bývalé radvanické pivnice a hotelu Gambrinus stoji dodnes $v$ severozápadní části ostravského Masarykova náměstí. V roce 2008 tam provozovaly své živnosti lékárna U zlaté koruny a solární studio.

\section{ARTHUR NEUMANN}

Po smrti Emanuela Neumanna v roce 1896 převzal vedení pivovaru a jemu príslušejících provozů Arthur Neumann. Za jeho působení byla roku 1901 sladovna vybavena moderními stroji, jako byly separátory, triery, elevátory, cyklóny a dalšími zařízeními na čištění ječmene a sladu. Šestnáctihodinová pracovní doba (od 2 do 18), stravování a pracovní podmínky byly $v$ pivovaru velmi špatné, to podněcovalo velké nepokoje mezi dělníky a ostravskými odborovými svazy a docházelo $\mathrm{k}$ mnohým stávkám. $\mathrm{V}$ této době se nadto velmi intenzívně projevila konkurence sousedních velkopivovarů, Neumannův pivovar s nimi nedokázal držet krok a výstav spadl z téměř $30000 \mathrm{hl}$ na přelomu 19. a 20. století na nějakých $6100 \mathrm{hl}$ během šesti let. $\mathrm{V}$ letech 1902-1908 dokonce Arthur Neumann sládkoval osobně. Nepříznivá situace vedla Arthura Neumana k prodeji pivovaru. Nepomohl ani profesor Alois Schwarz, specialista na pivovarskou technologii, zkušený poradce při modernizacích radvanického pivovaru a manžel Hedviky Neumannové (sestra Arthura Neumanna). Př́ílušníci Neumannovy dynastie byli nejenom zdatní obchodníci a průmyslníci, velmi aktivně se také zapojovali do komunální politiky a veřejného života, sponzorovali řadu nadací, spolků, veřejných staveb a vzdělávání. Arthur Neumann se po prodeji pivovaru odstěhoval do Vídně, kde žil jako rentiér. Navždy však zůstal radvanickým občanem a byl zde také pohřben. Tak jako většina z rozvětvené rodiny Neumannů.

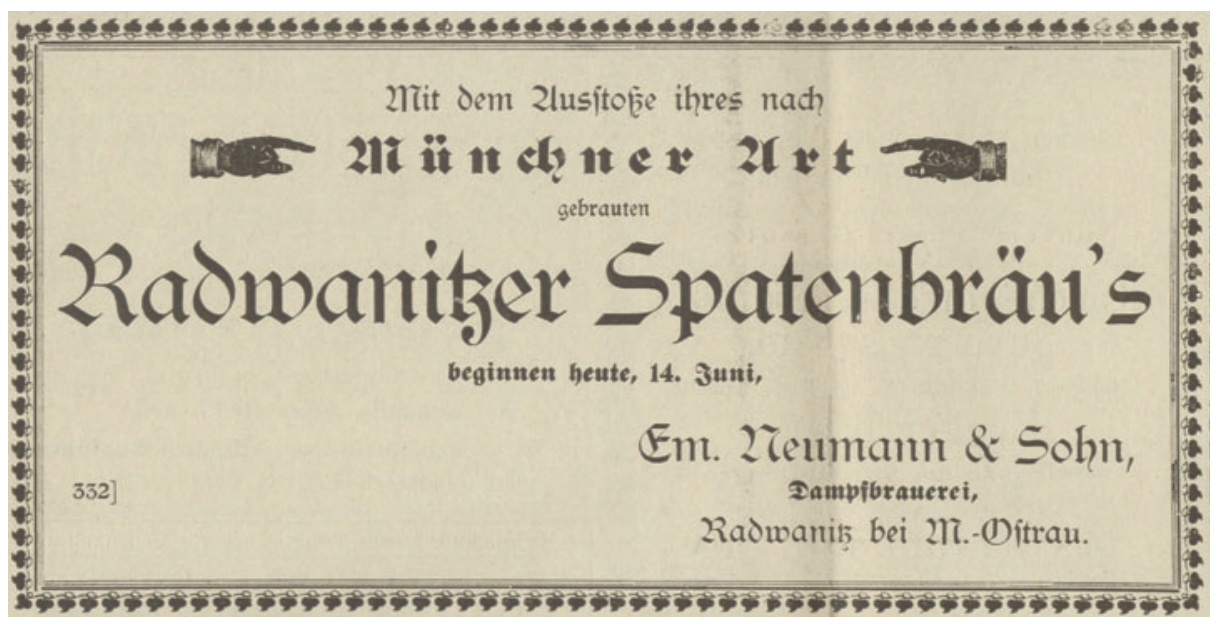

Obr. 1 Dobová etiketa. Zdroj Archiv města Ostravy. 


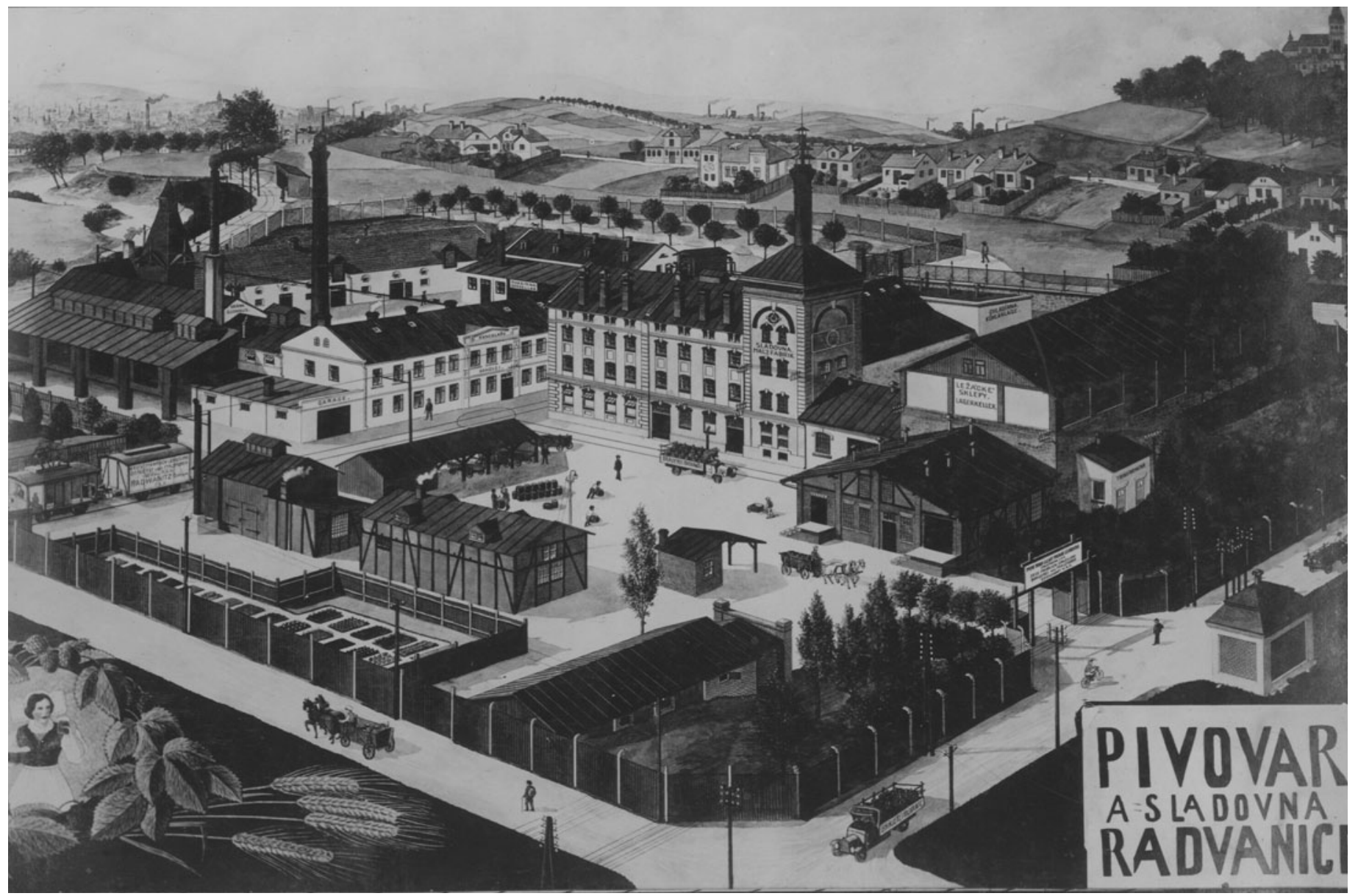

Obr. 2 Idealizovaný obrázek radvanického pivovaru. Zdroj Archiv města Ostravy.

Na počátku 20. století byla zprovozněna úzkorozchodná trat Ostrava - Karviná. Jedna ze zastávek v Radvanicích byla právě přímo u pivovaru, kde stávala známá trafika. Musel to být žíznivý pohled z kolébajícího se vagónu na pivovar $v$ plném laufu! Na tuto trat byl pivovar napojen vlečkou, která je zřetelná na idealizovaném obrázku pivovaru, kde jsou zřetelné i chladící pivní vagóny.

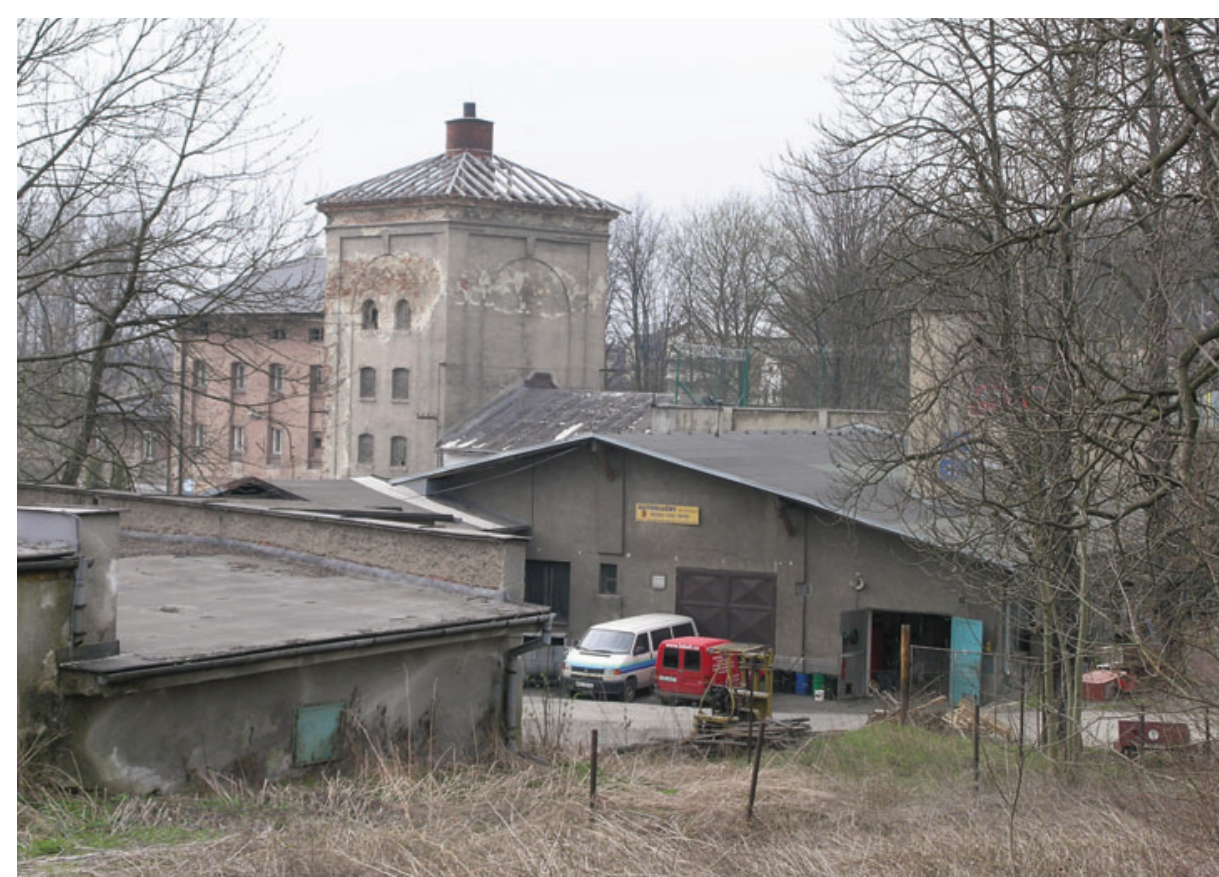

Obr. 3 Zbytky radvanického pivovaru. Foto autor 2007.

\section{DĚLNICKÝ PIVOVAR}

Roku 1908 koupilo pivovar beze skladů za 270000 korun od Arthura Neumanna vídeňské dělnické družstvo pod vedením Ferdinanda Skareta s názvem „První moravskoslezský dělnický pivovar Skaret a spol. v Radvanicích“ (někde uváděný jako: „Prvni moravsko-slezský dělnický pivovar Skaret,

Exner a spol.v Radvanicích“, jako majitelé byli uváděni F. Skaret a Dr. Benno Karpeles). Ti se inned pustili do rozsáhlých modernizací, pivovar elektrifikovali, varnu modernizovali a bylo možné svařovat dvě várky denně po $80 \mathrm{hl}$. Sladovalo se standardně v desetiměsíční kampani s maximální kapacitou 1000 tun ročně, sklepní hospodářství ve čtyřech odděleních mohlo pojmout zároveň $6000 \mathrm{hl}$, přičemž každé oddělení mělo 12 sudů po 60 hl, 10 sudů po $40 \mathrm{hl}, 2$ sudy po $25 \mathrm{hl} \mathrm{a} 5$ sudů po 18 hl. To udával časopis Naše Ostravsko roku 1909. Nicméně při jednoduchém vynásobení počtu sudů jejich objemem dojdeme ke kapacitě sklepa 5040 hl. A kde je zbývajících téměř 1000 hl? Domnívám se, že by to mohla být kapacita spilky a časopis kapacitou sklepa měl na mysli kapacitu chladného hospodářství. A nebo překlep. Pivovar zaměstnával 7 úředníků a 35 dělníků, sklady měl v Moravské Ostravě, Hrabůvce, Orlové, Bludovicích a Bašce. Dle údajů radvanické kroniky byl v této době dokonce zakoupen zimotvorný stroj, čímž se pivovar zařadil mezi opravdu nejmodernější závody v regionu. Inovace se neobešly bez značných úvěrů. Výstav piva strmě stoupal a v kampani 1912/1913 bylo dosaženo předprvoválečného maxima $35000 \mathrm{hl}$ vystaveného piva. $\mathrm{Na}$ sládkovském postu byl při tomto vzestupu Josef Černý, a to v letech 1909-1916. „Sociálnědemokratický pivovar" je status dosti ojedinělý. Tedy $v$ našich zemích. Někdy byl dokonce titulován jako „dělnický pivovar“. V dobovém tisku se popis ideálů sociálně-demokratického pivovaru nápadně podobal výrokům doby poúnorové. Však také dlouhého trvání „dělnické vedení" nemělo. 


\section{HYNEK LAUBER}

První světová válka znamenala druhý bolestný propad výroby radvanického pivovaru až na $5000 \mathrm{hl}$ vystaveného piva $\mathrm{v}$ sezoně 1916/17. Neschopnost splácet úvěry u holandských finančních ústavů plynoucí z propadu výroby znamenaly konec „dělnického pivovaru" a novými majiteli se stalo sedm společníků z Moravské Ostravy a Vídně. Ti po složení 1000000 korun základního jmění založili společnost „První moravsko-slezská pivovarská a sladařská spol. s r. o.“. Pivovar začal po válce velmi rychle prosperovat a již v sezoně 1920/21 dosáhl opět výstavu 35000 hl. Provoz byl neustále modernizován, což můžeme sledovat např. na objemu vyrážené mladiny. Byly zřizovány nové sklady a stáćíny radvanického piva (např. Sklad a stácírna radvanického piva Františka Šablatury ve Frenštátu pod Radhoštěm). V roce 1924 byl uváděn objem várky $80 \mathrm{hl}$, stejně jako $v$ době „dělnického pivovaru“, v roce 1928 byl var zvýšen na 100 hl, roku 1929 na $120 \mathrm{hl}$ a roku 1931 dokonce na $125 \mathrm{hl}$. Žrejmě se nejednalo vždy o zcela nové varny, ale nějaký způsob zefektivňování výroby. Dále byly instalovány motory $\mathrm{k}$ jednotlivým strojům náhradou za skupinový pohon hlavní transmise, což velmi snižovalo energetickou náročnost výroby. V letech 1925-1926 proběhla modernizace umělého chlazení, spilka byla vybavena novými káděmi, sklep novými ležáckými sudy a aluminiovými tanky o objemu 120 až $140 \mathrm{hl}$. Tanky ležely dokonce ve třech řadách nad sebou a to vzbuzuje domněnku o zatankování lednic v souvislosti s modernizací umělého chlazení. Hliníkové tanky, jako horká novinka své doby, pocházely zřejmě z dílen plzeňské Škodovky a v sousední Moravské Ostravě byly instalovány do obou pivovarů, které je využívaly ještě dlouho po druhé světové válce. Aluminiové tanky se používaly v pivovarském odvětví velmi sporadicky, a tudíž Ize jejich aplikaci ve třech sousedních průmyslových pivovarech považovat za Ostravský fenomén. Z dalších inovačních kroků jmenujme aplikaci nových plnících strojủ, rozšir̃ení administrativní budovy, adaptaci stájí na garáže či zřízení zámečnické dílny. Manipulační lednice pro hostinské a obchodníky měla kapacitu $2000 \mathrm{~m}^{3}$. Vodu pivovar odebíral původně ze studně pod nynějším hřbitovem a po zřízení hřbitova byla zbudována nová studna s kapacitou 8hl za minutu na pozemku pana Furmančíka. Uvedený zdroj však nepostačoval, a proto se používaly další pomocné studny menšího průtoku a slezskoostravský vodovod. Tato informace z kroniky Radvanic je z pivovarského hlediska neadekvátní a $8 \mathrm{hl}$ za minutu bylo naprosto dostačujícím množstvím vody varní i technologické pro nejvyšší výstavy radvanického pivovaru. Tudiž se naskýtá možnost překlepu či používání studny i pro jiné než pivovarské účely. Pivovar disponoval vlastní trafostanicí, jež transformovala $3000 \mathrm{~V}$ na $220 \mathrm{~V}$. V provoze bylo 37 motorů o celkové síle 200 koňských sil. Energeticky nejnáročnější zimotvor o kapacitě 100000 kalorií byl poháněn motorem o síle 75 koňských sil.

Z idealizovaného obrázku je zřejmé, že rozmístění budov bylo značně atypické a neustálé rozšiřování závodu je nasnadě. Zleva doprava vidíme říčku Lučinu a úzkokolejnou trat' se zastávkou a vlečkou do pivovaru, dále chladící štok, varní komín, strojovnu a komín ze strojovny, garáže, správní budovu, za správní budovou spilky a před správní budovou bednárnu, požahovnu a záhony, dále pi- vovarský dvưr a sladovnu, za sladovnou lednice, úplně v popředí starý sklep, vedle sladovny vpravo nové sklepy a vpravo v pozadí kostelík (obr. 2). Do dnešních dnů se z celého pivovaru dochovalo jen torzo (obr. 3). $\mathrm{Na}$ snímku zcela vlevo $v$ popředí je část starého pivovarského sklepa, v pozadí část sladovny s mohutným tělesem hvozdu a vpravo kdysi stávaly novější sklepy - nyní autodína.

Jedním z hlavních hybných sil pivovaru byl Hynek Lauber, který už od roku 1917 působil jako správce, od roku 1918 do ukončení provozu jako ředitel, dále také jako člen správní rady a pětinový vlastník. Dobře prosperující podnik byl 17. 10. 1925 přeměněn na akciovou společnost „První moravsko-slezský pivovar a sladovna akc. spol." se základním kapitálem 1000000 korun rozdělený na 5000 akcií po 200 korunách. Roku 1927 měl být základní kapitál navýšen na 2000000 korun, což zřejmě nebylo nikdy provedeno, nebot při zániku společnosti v letech 1944 - 1948 byl uváděn neustále kapitál 1000000 korun. Tato transformace neznamenala změnu majitelů, hlavními akcionáři zůstali ostravští a vídeňští obchodníci a do statutárních orgánů společnosti se dostali také zástupci samotné obce Radvanice. To mělo zřejmý kladný vliv na rozvoj závodu a podnik následoval trendy doby. Neustálé modernizace strojní i stavební vedly k nárůstu výroby. V kampani 1929/30 bylo dosaženo absolutního maxima 48000 hl vystaveného radvanického piva. Pivo bylo rozváženo pěti novými nákladními automobily a jedním párem koní nejenom do skladů v Príboru, Petřvaldě, Žilině, Košicích, Michalovcích, Hlohovci, Bratislavě, Sučanech, Petřkovicích, a Fryštátu, ale i na Podkarpatskou Rus. Pivovar zaměstnával cca 60 pracovníků s průměrnou týdenní mzdou 200 korun, v letech 1916-1926 držel sládkovské kormidlo Tomáš Mlčoch a jeho následníkem byl František Pittermann až do roku 1935. Sládek František Pittermann byl elegán, gentleman a milovník v každém ohledu, neustále $v$ obleku a v pivovaru na svém místě. Velká hospodářská krize znamenala počátek krachu pivovaru. Platební neschopnost odběratelů a následné zadlužení vedlo k neodvratnému ukončení činnosti. $\checkmark$ roce 1935 došlo $k$ vyrovnání věritelů a roku 1937 pivovar ukončil výrobu zcela. Černého sládkovského petra si vytáhl A. Čapoun. Do třetice, $v$ tomto prípadě, všeho zlého, pivovar třetí krizi nepřežil a v nedožitých osmdesáti letech ukončil svou činnost.

Sortiment pivovaru zahrnoval $10 \%$ výčepní světlé a tmavé, $12 \%$ Rekord světlé, $12 \%$ Kozel tmavé, 14\% Diamant světlé, 14\% Primátor tmavé, 16\% Porter speciální a Březňák. Zřejmě to byl sortiment za delší časové období, který se obměňoval a pivovar stěží vařil všechny druhy najednou. Na konci 19 . století byla oblíbena piva vařená po bavorském způsobu jako napríklad „Radwanitzer Spatenbräuś", inspirovaný proslulým klášterním pivovarem ve Spaten. Dle dobových tabulek se sortiment pivovaru skládal ze $75 \%$ z piva výčepního a 25 \% z ležáku. Podíl speciálních piv byl zanedbatelný.

\section{EPILOG}

Po ukončení výroby piva radvanického sloužily budovy pivovaru jako sklad piva karvinského. Dle vyprávění pamětníků prý hrabě Larisch-Mönnich dokonce radvanický pivovar koupil i s jeho odběrateli. To však není potvr- zeno. Vzhledem ke skutečnosti, že byly oba pivovary spojeny úzkorozchodnou dráhou Ostrava - Karviná, tak by to bylo i logické z hlediska zásobování radvanického skladu karvinským pivem po trati. Druhá světová válka rozvoj karvinského pivovaru zastavila a sklad piva byl roku 1940 zrušen. Pivovarské budovy spravoval národní správce a usídlila se $v$ nich výrobna nábytku, výrobna dopravních gumových pásů a prodejna potřeb pro šachty. Roku 1944 areál koupilo město Moravská Ostrava. Postupem doby byly jednotlivé budovy asanovány včetně honosné Neumannovy vily. Ta byla dle vyprávění místních usedlíků zbourána v polovině 80 . let 20 . století omylem místo sladovny, která částečně stojí doposud. Pivovarské provozy byly rozmístěny velmi atypicky a do dnešních dnů se zachoval jen starý sklep, který je zapuštěn směrem pod ulici Lihovarská. Do poloviny roku 2008 v něm sídlila společnost Moravské vinařské závody a dnes zeje prázdnotou. A jak již bylo uvedeno, dodnes se také zachovala část sladovny $s$ monumentálním tělesem hvozdu. Dokonce proběhly i částečné renovační kroky a relikt sladovny dostal novou střešní krytinu. Dříve se na humnech pěstovaly žampiony a dnes zde sídlí soukromé firmy. Ostatní budovy byly zcela asanovány. $\checkmark$ roce 2008 byla ještě zřetelná část obvodového zdiva nových sklepů pod parkovištěm vedle pekárny MAYAK. Sousední osobitá budova lihovaru byla na konci roku 2008 asanována a na jejím místě vykvetl fádní Penny.

\section{Použitá literatura}

Bakala, J., Borák, M, Gracová, B., Grobelný, A., Jiř́ik, K., Klíma, B., Myška, M., Pitronová, B., Steiner, J.: Dějiny Ostravy, Sfinga, Ostrava 1993.

Daněk, R.: Texty k výstavě Ostrava do bílé pěny oděná, Galerie Budoucnost 2008.

Daněk, R. Měštanský pivovar v Moravské Ostravě $v$ době průmyslové revoluce (1823-1889). Ostrava. Příspěvky k dějinám a současnosti Ostravy a Ostravska 22. Šenov u Ostravy: Statutární město Ostrava - Archiv města Ostravy / Nakladatelství Tilia, 2005. s. 59-89.

Daněk, R.: Ostravské pivovary mezi volnou soutěží a kartelem (1889-1918). Ostrava. Příspěvky k dějinám a současnosti Ostravy a Ostravska, 23. Šenov u Ostravy: Nakladatelství Tilia, 2007. s. 417-446.

Daněk, R.: Podnikatelská rodina Neumannů z Radvanic u Ostravy. In: Židé a Morava. Sborník z konference konané v Muzeu Kroměřížska dne 3. listopadu 2004. Kroměříž, Muzeum Kroměřížska 2005, s. 78-86.

Joklová, D., Semecký, J. a kol.: Radvanice a Bartovice v letopisech a obrazech. Ostrava: Městský obvod Radvanice a Bartovice statutárního města Ostravy, 2005.

Kneifel, R.: Topographie des k. k. Antheils von Schlesien. Brünn 1804-1806.

Likovský, Z.: Pivovary Československého území 1900 - 1948, VÚPS, Praha 2006.

Likovský, Z.: Pivovary Moravy a rakouského Slezska 1869-1900, VúPS, Praha 2000. Radvanický pivovar. Naše Ostravsko, 1909. Radvanice kronika, Archiv města Ostravy. SOA Karviná, Stavba pivovaru Richarda Neumanna v Radvanicích s přip. plány, i.č. 335, k. 128.

SOA Karviná, Stávka 6 sladovníků v pivovaru v Radvanicích ..., i.č. 3773, sign. 8707, k. 117. 